\title{
CRIMINAL JUSTICE EDUCATION IN THE UNITED STATES: A PROFILE
}

\author{
RICHARD R. BFNNFTT
}

Associate Research Scientist Highway Safety Research Institute

The University of Michigan

Ann Arbor, Michigan 48109

INEKE HAEN MARSHALL

Assistant Professor

Department of Criminal Justice

Youngstown State University

Youngstown, Ohio 44555

\begin{abstract}
Various commissions from the Wickersham (1931) to the National Advisory Commission on Higher Education for Police (1978) have called for the upgrading of police educational levels. Junior colleges, colleges and universities have responded by creating a plethora of educational programs. However, currently, little is known about the nature, form, or practice of criminal justice education in the United States. In attempting to fill this void, data from the Law Enforcement Education Program (LEEP) are presented concerning the number of students, criminal justice majors, and degrees awarded as well as institutional control, location, and type. These previously unpublished data are presented in a primary form (frequency distributions and cross-tabulations) to allow the reader to draw conclusions about the nature and scope of criminal justice education. Brief interpretations, however, are provided.
\end{abstract}




\section{INTRODUCTION}

In the past ten years, higher education in criminal justice has undergone rapid growth both as a serious academic field of study and as a college major selected by students. From criminal justice education's meager beginnings (184 programs in 1966) (Kobetz, 1975), it has grown to where approximately 200,000 students are enrolled in over a thousand programs. Currently, the federal government spends an estimated $\$ 80$ million each year in direct and indirect academic assistance to these programs and their students.

The need for higher education in criminal justice was officially recognized as early as 1931 in the conclusions and recommendations of the National Commission on Law Observance and Enforcement (Wickersham Commission). Subsequent governmental studies and commissions have echoed this need. The President's Commission on Law Enforcement and Administration of Justice (1967), the National Advisory Commission on Civil Disorders (1968), the National Commission on the Causes and Prevention of Violence (1969), the National Advisory Commission on Criminal Justice Standards and Goals (1973), and the National Advisory Commission on Higher Education for Police Officers (1978) all proclaim the need for improving the educational standards of criminal justice personnel, especially the police, who are traditionally recruited from the less educated segments of society. The President's Commission on Law Enforcement and Administration of Justice stated as long as twelve years ago:

The quality of police service will not significantly improve until higher educational requirements are established for its personnel. Due to the nature of the police task and its effect on our society, there is need to elevate educational requirements to the level of a college degree from an accredited institution for all future personnel selected to perform the functions of a police agent. The demands on the police should preclude a lower requirement for persons responsible for confronting major crime and social problems. $(1967: 126)$

The National Advisory Commission on Criminal Justice Standards and Goals (1973) attempted to encourage implementation of educational standards by presenting specific time-frame recommendations. The report reads: "The standards contained in this chapter would require all police officers to have an undergraduate degree or its equivalent no later than 1982' (p. 367).

In response to this governmental interest, a plethora of academic programs directed at fulfilling this need has been created. However, little is known about the nature of these academic programs, their course content, methods of instruction, student enrollment, faculty expertise and qualifications, and the relationship between the effects of higher education and the needs of the profession. As an example, although current literature discusses such issues as course content (Smith, 1977; Sherman et al., 1978; Brantingham, 1972; Kuykendall and Hernandez, 1975; Lejins, 1970; Mathias, 1969; Hoover, 1975; Moynahan, 1969), the relationship between education and training (Sherman et al., 1978; Aaron, 1965; Ashburn and Ward, 1973; Brown, 1971; Cromwell, 1972; Parker, 1973; Prout, 1972; Saunders, 1970; Wilson, 1974), liberal arts versus professional education (Brown, 1974; Lankes, 1970; Moynahan, 1973; Sherman et al., 1978), academic or practitioner control of curriculum, (Aaron, 1965; Sherman, 1977; Wilson, 1974) education and professionalism (Gourley, 1972; Gambino, 1973; Germann, 1967; Gould, 
1973; Lynch, 1976), and quality of instructional personnel (Sherman et al., 1978), little empirical evidence exists that would document the validity of any of these issues. In addition, current empirical evidence pertaining to the effect of education on police performance is scant, conflicting, and ambiguous. Researchers such as Geary (1970, 1971), Finnigan (1976), Roberg (1976), Cohen and Chaiken (1972), Baeher, Furcon, and Froemel (1968), Trojanowicz and Nicholson (1976), Christian (1976), Cascio and Real (1976), Cascio (1977), and Witte (1969) have observed a positive relationship between levels of education and quality of performance. Conversely, other researchers (Bennett, 1978; Smith and Ostrom, 1974; Matarazzo, Allen, Saslow, and Wiens, 1964; McGreevy, 1964) observed a weak or negative relationship between education and the quality of police performance. In short, although many studies have been undertaken, their findings are equivocal and the validity of our efforts in the area of education is in question.

Before addressing educational issues further, more information is needed about the actual nature of criminal justice programs, the students they serve, and the institutional environment in which they are housed. This report is designed to fill this informational void by presenting descriptive data documenting the scope of criminal justice education in the United States. It provides a previously unpublished accounting of nationwide data on selected characteristics of institutions and students. The data are presented in as primary a form as possible (frequency distributions and cross-tabulations) so that readers may use this information to draw their own conclusions.

\section{DATA}

The data presented in this report were secured from the Office of Criminal Justice Education and Training's (OCJET) Law Enforcement Education Program (LEEP). LEEP was initiated in 1968 under the authority of the Omnibus Crime Control and Safe Streets Act of 1968. The purpose of this program is to supply federal financial aid to students enrolled in criminal justice, criminology, or related educational programs. Interested institutions apply for funds by supplying information about the nature of the program, i.e. the student, faculty, and institutional characteristics. Based on this information, OCJET distributes LEEP funds to the institutions. The institution, then, distributes the allocated funds to its students based on LEEP guidelines.

The institutions included represent one of the most comprehensive available listings of criminal justice, criminology, and related programs. Still the list is not complete. Only those institutions that initiated the application process and met the program's qualifications are included in the LEEP data base. No systematic sampling procedures were undertaken by OCJET in the compilation of the data base. The actual number of programs, therefore, remains unknown, and the representativeness of the programs included cannot be determined. ${ }^{1}$ However, the LEEP-based data do provide an informative picture of the characteristics of those criminal justice programs that are directly supported by government funds specifically allocated to criminal justice education.

The source of the data contained in this publication was the LEEP 1 Form. Each participating institution had to complete this form before receiving funds. On completing the form, the institution forwarded the form to the appropriate regional office. (These offices were discontinued as of the 1977-78 academic year.) The regional LEEP office coded the forms, checked for obvious errors, and sent them to the Washington office. If 
the form was incomplete or incorrectly filled out, the regional office either returned the form to the institution or telephoned the institution for the additional information.

Although LEEP data concerning criminal justice programs have been collected since the inception of the program, the quality and especially completeness of the data prior to 1976 is questionable. Therefore, we have presented only the data from the academic years 1976-77 and 1977-78. Trend analysis must await future data collection.

The data presented in this report should be used with caution. Three potential sources of bias exist as a result of data collection and analysis. First, as discussed earlier, the institutions represented are self-selected (i.e., only those that applied for LEEP funds), and the resulting list of institutions offering criminal justice related programs cannot be considered inclusive. Second, the data supplied by the institutions have not been audited for accuracy, and thus the validity of the data cannot be determined. Although cases of program misrepresentation are extremely infrequent, there is evidence that it has happened. Further, although discovery and correction of computational errors was facilitated by incorporating a validity check mechanism within the original LEEP computer program, these mechanisms demonstrated limited effectiveness. Finally, errors were encountered in the coding of the LEEP form by the regional offices. There appeared to be a lack of coordination and agreement among regional offices as to what codes should be used. The authors corrected all code discrepancies that were identified before their analyses. However, it is likely that other discrepancies were not detected.

The data are presented in two forms. The first and second parts of the report contain frequency distributions and percentages pertaining to student enrollment, degrees awarded, and the institutional environment. Parts three and four present tables in which these data are cross-tabulated with data pertaining to institutional type and control. ${ }^{2}$ It must be noted that these data are based on an institutional level of analysis and, therefore, student characteristics can only be estimated.

As a final note, one will observe that the size of the sample will vary from one table to the next. This variance is caused by the individual institutions not responding to all questions contained on the LEEP form. Furthermore, some of the question categories were not mutually exclusive. Thus, one institution could be represented more than once in the "total" of each table. As an example, one institution might offer three majors (police, courts, and corrections) and therefore be counted in the column totals as three institutions instead of one.

\section{A GENERAI, PROFII E}

Tables 1 through 4 present data related to location, type of institution, and institutional control of criminal justice programs in the United States. The data are presented by schools and by years. Each table includes the number of schools in each category as well as its percent of the total. Perecntage totals are calculated for each column. ${ }^{3}$ For purposes of simplicity, only the data for 1977 will be discussed.

Tables 1 and 2 present data on the location of criminal justice programs in the United States. Table 1 shows the number of programs located in each state or territory. Texas contains the greatest number of programs $(80)$ while the Virgin Islands has the fewest (1). However, when comparing the number of schools to the states' populations, Wyoming has the greatest number of programs (one program for each 78,000 persons) 
TABLE 1

Criminal Justice Programs, by State

\begin{tabular}{|c|c|c|c|c|c|c|c|c|}
\hline & \multicolumn{2}{|c|}{ Schools } & & \multicolumn{2}{|c|}{ Schools } & & \multicolumn{2}{|c|}{ Schools } \\
\hline & 1976 & 1977 & & 1976 & 1977 & & 1976 & 1977 \\
\hline Alabama & $\begin{array}{c}25 \\
(2.4)\end{array}$ & $\begin{array}{c}25 \\
(2.5)\end{array}$ & Maine & $\begin{array}{c}6 \\
(0.6)\end{array}$ & $\begin{array}{c}6 \\
(0.6)\end{array}$ & Orcgon & $\begin{array}{c}18 \\
(1.8)\end{array}$ & $\begin{array}{c}19 \\
(1.9)\end{array}$ \\
\hline Alaska & $\begin{array}{c}2 \\
(0.2)\end{array}$ & $\begin{array}{c}2 \\
(0.2)\end{array}$ & Maryland & $\begin{array}{c}18 \\
(1.8)\end{array}$ & $\begin{array}{c}18 \\
(I .8)\end{array}$ & Pennsylvania & $\begin{array}{c}36 \\
(3.5)\end{array}$ & $\begin{array}{c}34 \\
(3.3)\end{array}$ \\
\hline Arizona & $\begin{array}{c}14 \\
(1.4)\end{array}$ & $\begin{array}{c}14 \\
(I .4)\end{array}$ & Massachusetts & $\begin{array}{c}28 \\
(2.7)\end{array}$ & $\begin{array}{c}28 \\
(2.6)\end{array}$ & Rhode Island & $\begin{array}{c}4 \\
(0.4)\end{array}$ & $\begin{array}{c}4 \\
(0.4)\end{array}$ \\
\hline Arkansas & $\begin{array}{c}15 \\
(1.5)\end{array}$ & $\begin{array}{c}16 \\
(I .6)\end{array}$ & Michigan & $\begin{array}{c}44 \\
(4.3)\end{array}$ & $\begin{array}{c}45 \\
(4.4)\end{array}$ & South Carolina & $\begin{array}{c}15 \\
(1.5)\end{array}$ & $\begin{array}{c}15 \\
(1.5)\end{array}$ \\
\hline California & $\begin{array}{c}60 \\
(5.8)\end{array}$ & $\begin{array}{c}48 \\
(4.7)\end{array}$ & Minnesota & $\begin{array}{c}23 \\
(2.2)\end{array}$ & $\begin{array}{c}23 \\
(2.3)\end{array}$ & South Dakota & $\begin{array}{c}5 \\
(0.5)\end{array}$ & $\begin{array}{c}5 \\
(0.5)\end{array}$ \\
\hline Colorado & $\begin{array}{c}16 \\
(1.6)\end{array}$ & $\begin{array}{c}15 \\
(1.5)\end{array}$ & Mississippi & $\begin{array}{c}13 \\
(1.3)\end{array}$ & $\begin{array}{c}13 \\
(1.3)\end{array}$ & Tennessee & $\begin{array}{c}15 \\
(1.5)\end{array}$ & $\begin{array}{c}15 \\
\text { (l.5) }\end{array}$ \\
\hline Connecticut & $\begin{array}{c}12 \\
(1.2)\end{array}$ & $\begin{array}{c}13 \\
(1.3)\end{array}$ & Missouri & $\begin{array}{c}26 \\
(2.5)\end{array}$ & $\begin{array}{c}30 \\
(3.0)\end{array}$ & Texas & $\begin{array}{c}82 \\
(8.0)\end{array}$ & $\begin{array}{c}80 \\
(7.9)\end{array}$ \\
\hline Delaware & $\begin{array}{c}6 \\
(0.6)\end{array}$ & $\begin{array}{c}6 \\
(0.6)\end{array}$ & Montana & $\begin{array}{c}6 \\
(0.6)\end{array}$ & $\begin{array}{c}6 \\
(0.6)\end{array}$ & Utah & $\begin{array}{c}3 \\
(0.3)\end{array}$ & $\begin{array}{c}3 \\
(0.3)\end{array}$ \\
\hline $\begin{array}{l}\text { District of } \\
\text { Columbia }\end{array}$ & $\begin{array}{c}5 \\
(0.5)\end{array}$ & $\begin{array}{c}5 \\
(0.5)\end{array}$ & Nebraska & $\begin{array}{c}6 \\
(0.6)\end{array}$ & $\begin{array}{c}\mathbf{6} \\
(0.6)\end{array}$ & Vermont & $\begin{array}{c}6 \\
(0.6)\end{array}$ & $\begin{array}{c}6 \\
(0.6)\end{array}$ \\
\hline Florida & $\begin{array}{c}38 \\
(3.7)\end{array}$ & $\begin{array}{c}41 \\
(4.0)\end{array}$ & Nevada & $\begin{array}{c}5 \\
(0.5)\end{array}$ & $\begin{array}{c}6 \\
(0.5)\end{array}$ & Virginia & $\begin{array}{c}30 \\
(2.9)\end{array}$ & $\begin{array}{c}28 \\
(2.8)\end{array}$ \\
\hline Georgia & $\begin{array}{c}28 \\
(2.7)\end{array}$ & $\begin{array}{c}31 \\
(3.1)\end{array}$ & New Hampshire & $\begin{array}{c}2 \\
(0.2)\end{array}$ & $\begin{array}{c}2 \\
(0.2)\end{array}$ & Washington & $\begin{array}{c}32 \\
(3.1)\end{array}$ & $\begin{array}{c}30 \\
(3.0)\end{array}$ \\
\hline Idaho & $\begin{array}{c}4 \\
(0.4)\end{array}$ & $\begin{array}{c}4 \\
(0.4)\end{array}$ & New Jersey & $\begin{array}{c}27 \\
(2.6)\end{array}$ & $\begin{array}{c}27 \\
(2.7)\end{array}$ & West Virginia & $\begin{array}{c}8 \\
(0.8)\end{array}$ & $\begin{array}{c}8 \\
(0.8)\end{array}$ \\
\hline Illinois & $\begin{array}{c}54 \\
(5.3)\end{array}$ & $\begin{array}{c}54 \\
(5.3)\end{array}$ & New Mexico & $\begin{array}{c}7 \\
(0.7)\end{array}$ & $\begin{array}{c}7 \\
(0.7)\end{array}$ & Wisconsin & $\begin{array}{c}21 \\
(2.0)\end{array}$ & $\begin{array}{c}19 \\
(1.9)\end{array}$ \\
\hline Indiana & $\begin{array}{c}15 \\
(1.5)\end{array}$ & $\begin{array}{c}15 \\
(1.5)\end{array}$ & New York & $\begin{array}{c}72 \\
(7.0)\end{array}$ & $\begin{array}{c}74 \\
(7.3)\end{array}$ & Wyoming & $\begin{array}{c}5 \\
(0.5)\end{array}$ & $\begin{array}{c}5 \\
(0.5)\end{array}$ \\
\hline Iowa & $\begin{array}{c}22 \\
(2.1)\end{array}$ & $\begin{array}{c}21 \\
(2.1)\end{array}$ & North Carolina & $\begin{array}{c}23 \\
(2.2)\end{array}$ & $\begin{array}{c}22 \\
(2.2)\end{array}$ & Hawaii & $\begin{array}{c}7 \\
(0.7)\end{array}$ & $\begin{array}{c}7 \\
(0.7)\end{array}$ \\
\hline Kansas & $\begin{array}{c}20 \\
(1.9)\end{array}$ & $\begin{array}{c}17 \\
(1.7)\end{array}$ & North Dakota & $\begin{array}{c}4 \\
(0.4)\end{array}$ & $\begin{array}{c}4 \\
(0.4)\end{array}$ & Puerto Rico & $\begin{array}{c}4 \\
(0.4)\end{array}$ & $\begin{array}{c}2 \\
(0.2)\end{array}$ \\
\hline Kentucky & $\begin{array}{c}12 \\
(1.2)\end{array}$ & $\begin{array}{c}13 \\
(1.3)\end{array}$ & Ohio & $\begin{array}{c}39 \\
(3.8)\end{array}$ & $\begin{array}{c}39 \\
(3.8)\end{array}$ & Virgin Islands & $\begin{array}{c}1 \\
(0.1)\end{array}$ & $\begin{array}{c}1 \\
(0.1)\end{array}$ \\
\hline Louisiana & $\begin{array}{c}15 \\
(1.5)\end{array}$ & $\begin{array}{c}15 \\
(1.5)\end{array}$ & Oklahoma & $\begin{array}{c}23 \\
(2.2)\end{array}$ & $\begin{array}{c}23 \\
(2.3)\end{array}$ & Total & $\begin{array}{r}1027 \\
(100.3)\end{array}$ & $\begin{array}{r}1015 \\
(100.7)\end{array}$ \\
\hline
\end{tabular}

NOTE: Percentages (given in parentheses) are rounded to the nearest tenth and may not total $100 \%$. 
TABLE 2

Criminal Justice Programs, By Region

\begin{tabular}{|c|c|c|}
\hline \multicolumn{3}{|c|}{ SCHOOLS } \\
\hline REGION* & 1976 & 1977 \\
\hline 1 & $\begin{array}{c}58 \\
(5.6)\end{array}$ & $\begin{array}{c}59 \\
(5.8)\end{array}$ \\
\hline II & $\begin{array}{c}105 \\
(10.2)\end{array}$ & $\begin{array}{c}104 \\
(10.2)\end{array}$ \\
\hline III & $\begin{array}{c}103 \\
(10.0)\end{array}$ & $\begin{array}{c}100 \\
(9.9)\end{array}$ \\
\hline IV & $\begin{array}{c}169 \\
(16.4)\end{array}$ & $\begin{array}{c}174 \\
(17.1)\end{array}$ \\
\hline V & $\begin{array}{c}196 \\
(19.1)\end{array}$ & $\begin{array}{c}195 \\
(19.2)\end{array}$ \\
\hline VI & $\begin{array}{c}142 \\
(13.8)\end{array}$ & $\begin{array}{c}141 \\
(13.9)\end{array}$ \\
\hline VII & $\begin{array}{c}74 \\
(7.2)\end{array}$ & $\begin{array}{c}74 \\
(7.3)\end{array}$ \\
\hline VIII & $\begin{array}{c}39 \\
(3.8)\end{array}$ & $\begin{array}{c}38 \\
(3.7)\end{array}$ \\
\hline IX & $\begin{array}{c}86 \\
(8.4)\end{array}$ & $\begin{array}{c}75 \\
(7.4)\end{array}$ \\
\hline $\mathrm{X}$ & $\begin{array}{c}56 \\
(5.4)\end{array}$ & $\begin{array}{c}55 \\
(5.4)\end{array}$ \\
\hline Total & $\begin{array}{l}1028 \\
(99.9)\end{array}$ & $\begin{array}{c}1015 \\
(99.9)\end{array}$ \\
\hline
\end{tabular}

NOTE: Percentages (given in parentheses) are rounded to the nearest tenth and may not total $100 \%$.

*States in each region. Region I: ME, VT, NH, MA, RI, CT; Region II: NY, NJ, PR, VI; Region III: PA, WV, VA, DE, MD, DC; Region IV: KY, TN, NC, SC, GA, AL, MS, FL; Region V: MN, WI, MI, OH, IN, IL; Region VI: NM, OK, AR, TX, LA; Region VII: NE, IA, MO, KS; Region VIII: MT, ND, SD, WY, UT, CO; Region IX: NV, CA, GU, AZ, HI; Region X: AK, WA, OR, ID.

(Bureau of Census, 1977), while, perhaps surprisingly, California has the fewest (one program per 448,300 persons). On the average there is one criminal justice program for each 210,000 people in the United States. The states with the most programs per population are Vermont $(1: 79,300)$, Delaware $(1: 97,000)$, and Nevada $(1: 101,600)$. The states with the fewest are New Hampshire $(1: 411,000)$, Utah $(1: 409,300)$, Indiana $(1: 353,500)$, and Pennsylvania $(1: 348,800)$. It is interesting to note that neighboring states exhibit such wide discrepancies.

Table 2 presents the number of programs by the ten federally defined LEAA regions (these regions do not correspond to census regions). Region V (Minnesota, Wisconsin, 
TABLE 3

Criminal Justice Programs, by Type of Institution

\begin{tabular}{lcc}
\hline TYPE OF & \multicolumn{2}{c}{ SCHOOLS } \\
INSTITUTION & 1976 & 1977 \\
\hline University & 173 & 170 \\
& $(16.9)$ & $(16.8)$ \\
Four-Year & 378 & 374 \\
& $(36.8)$ & $(37.0)$ \\
Two-Year & 474 & 468 \\
& $(46.2)$ & $(46.2)$ \\
\cline { 2 - 3 } Total & 1025 & 1012 \\
& $(99.9)$ & $(100.0)$ \\
\hline
\end{tabular}

NOTE: Percentages (given in parentheses) are rounded to the nearest tenth and may not total $100 \%$.

TABLE 4

Criminal Justice Programs, by institutional Control

\begin{tabular}{|c|c|c|}
\hline \multirow{2}{*}{$\begin{array}{l}\text { INSTITUTIONAL } \\
\text { CONTROL }\end{array}$} & \multicolumn{2}{|c|}{ SCHOOLS } \\
\hline & 1976 & 1977 \\
\hline Public & $\begin{array}{r}772 \\
(755)\end{array}$ & $\begin{array}{r}749 \\
(74 ?)\end{array}$ \\
\hline \multirow[t]{2}{*}{ Private } & 250 & 260 \\
\hline & $(24.5)$ & $(25.8)$ \\
\hline \multirow[t]{2}{*}{ Total } & 1022 & 1009 \\
\hline & & \\
\hline
\end{tabular}

NOTE: Percentages are given in parentheses.

Michigan, Ohio, Indiana, and Illinois) contains more programs than any other region (195), while Region VIII (Nebraska, Iowa, Missouri, and Kansas) contains the fewest (38). Again, when comparing the number of programs by the region's population, a different picture emerges. Region X (Alaska, Washington, Oregon, and Idaho) with only 55 programs has the lowest program-to-population ratio $(1: 130,000)$, while Region IX (Nevada, California, Arizona, Hawaii, and Guam), with only 75 programs, has the high- 
est $(1: 337,000)$. The highly populated regions, Regions IV and V, have program-to-population ratios of $1: 203,000$ and $1: 230,000$, respectively. Thus, it appears that population density is not related to the number of programs contained in the region.

Table 3 divides programs by type of institution. The type of educational institution in which the criminal justice program resides is likely to influence its educational philosophy, the composition of its faculty, and the student body, to mention but a few characteristics that may have a bearing on the quality of education (Sherman et al., 1978; National Planning Association, 1976). The largest number of programs appear to be housed in two-year institutions $(\mathrm{N}=468 ; 46$ percent of the total). Universities (defined as institutions that grant four-year and graduate degrees) house the smallest number of criminal justice programs $(\mathrm{N}=170 ; 17$ percent of the total). Four-year institutions (granting bachelor degrees and sometimes two-year associate degrees) contain 374 (37 percent of the total) of the 1,012 criminal justice programs surveyed.

Finally, Table 4 divides programs by institutional control. The designation of public or private refers to whether the institution is publicly or privately funded and controlled. The vast majority of programs are found in public institutions (74.2\%).

\section{A STUDENT PROFILE}

Tables 5 through 10 present data on program enrollment, degrees awarded, and academic major. Again, we wish to remind the reader that the data presented pertain

TABLE 5

Criminal Justice Programs, by Enrollment in Criminal Justice Program

\begin{tabular}{ccc}
\hline STUDENTS ENROLLED IN & \multicolumn{2}{c}{ SCHOOLS } \\
CRIMINAL JUSTICE PROGRAMS & 1976 & 1977 \\
\hline $1-199$ & 619 & 700 \\
$200-399$ & $(68.2)$ & $(71.8)$ \\
& 174 & 167 \\
$400-599$ & $(19.2)$ & $(17.1)$ \\
& 53 & 49 \\
$600-799$ & $(5.8)$ & $(5.0)$ \\
& 27 & 27 \\
$800-999$ & $(3.0)$ & $(2.8)$ \\
& 16 & 13 \\
Over 1000 & $(1.8)$ & $(1.3)$ \\
& 18 & 19 \\
Total & $(2.0)$ & $(1.9)$ \\
\hline & 907 & 975 \\
& $(100)$ & $(99.9)$ \\
\hline
\end{tabular}

NOTE: Percentages (given in parentheses) are rounded to the nearest tenth and may not total $100 \%$. 
TABLE 6

Number AND TyPe OF CRIMINal Justice DegreEs AWARDED

\begin{tabular}{|c|c|c|c|c|c|c|c|c|}
\hline \multirow{2}{*}{$\begin{array}{l}\text { NUMBER OF } \\
\text { DEGREES } \\
\text { AWARDED }\end{array}$} & \multicolumn{8}{|c|}{ TYPE OF DEGREE AWARDED } \\
\hline & $\begin{array}{c}\text { Asso } \\
1976\end{array}$ & $\begin{array}{l}\text { ate's } \\
1977\end{array}$ & \multicolumn{2}{|c|}{ Bachelor's } & Master's & $\begin{array}{l}\text { ter's } \\
1977\end{array}$ & $\begin{array}{c}P \\
1976\end{array}$ & $\begin{array}{l}\text { D. } \\
1977\end{array}$ \\
\hline $1-9$ & $\begin{array}{r}269 \\
(50)\end{array}$ & $\begin{array}{r}270 \\
(51)\end{array}$ & $\begin{array}{r}232 \\
(58)\end{array}$ & $\begin{array}{r}227 \\
(54)\end{array}$ & $\begin{array}{r}139 \\
(74)\end{array}$ & $\begin{array}{r}162 \\
(73)\end{array}$ & $\begin{array}{c}25 \\
(96)\end{array}$ & $\begin{array}{r}31 \\
(97)\end{array}$ \\
\hline $10-19$ & 123 & 105 & 67 & 81 & 30 & 35 & 1 & 1 \\
\hline $20-29$ & $\begin{array}{r}(23) \\
63\end{array}$ & $\begin{array}{r}(20) \\
53\end{array}$ & $\begin{array}{r}(17) \\
40\end{array}$ & $\begin{array}{r}(19) \\
43\end{array}$ & $\begin{array}{r}\text { (16) } \\
7\end{array}$ & $\begin{array}{r}(16) \\
12\end{array}$ & (4) & $\frac{(3)}{-}$ \\
\hline & (12) & (10) & (10) & (10) & (4) & (5) & - & - \\
\hline $30-39$ & 31 & 37 & 25 & 21 & 3 & 4 & - & - \\
\hline & (6) & (7) & (6) & (5) & (2) & (2) & — & - \\
\hline $40-49$ & 12 & 20 & 8 & 15 & 2 & - & - & - \\
\hline & (2) & (4) & (2) & (4) & (1) & - & - & - \\
\hline 50 or more & 43 & 41 & 30 & 32 & 8 & 8 & - & - \\
\hline & $(8)$ & $(8)$ & $(8)$ & (4) & (4) & - & - & \\
\hline Total & $\begin{array}{r}541 \\
(101)\end{array}$ & $\begin{array}{r}526 \\
(100)\end{array}$ & $\begin{array}{r}402 \\
(101)\end{array}$ & $\begin{array}{r}419 \\
(100)\end{array}$ & $\begin{array}{r}189 \\
(101)\end{array}$ & $\begin{array}{r}221 \\
(100)\end{array}$ & $\begin{array}{c}26 \\
(100)\end{array}$ & $\begin{array}{c}32 \\
(100)\end{array}$ \\
\hline
\end{tabular}

NOTE: Percentages (given in parentheses) are rounded to the nearest whole number and may not total $100 \%$.

TABLE 7

Police, Corrections, and Courts Majors

\begin{tabular}{lcccccc}
\hline CRIMINAL & \multicolumn{2}{c}{ ACADEMIC MAJOR } \\
JUSTICE & \multicolumn{2}{c}{ Police } & \multicolumn{2}{c}{ Corrections } & \multicolumn{2}{c}{ Courts } \\
MAJORS & 1976 & 1977 & 1976 & 1977 & 1976 & 1977 \\
\hline \multirow{2}{*}{$1-24$} & 258 & 282 & 472 & 499 & 397 & 433 \\
& $(30)$ & $(30)$ & $(71)$ & $(69)$ & $(91)$ & $(91)$ \\
$25-49$ & 186 & 256 & 104 & 131 & 24 & 34 \\
& $(22)$ & $(27)$ & $(16)$ & $(18)$ & $(6)$ & $(7)$ \\
$50-74$ & 119 & 129 & 43 & 46 & 10 & 8 \\
& $(14)$ & $(14)$ & $(7)$ & $(6)$ & $(2)$ & $(2)$ \\
$75-99$ & 91 & 68 & 16 & 24 & 3 & 1 \\
& $(11)$ & $(7)$ & $(2)$ & $(3)$ & $(1)$ & $(0)$ \\
100 or more & 212 & 201 & 29 & 26 & 2 & 2 \\
& $(25)$ & $(22)$ & $(4)$ & $(4)$ & $(1)$ & $(0)$ \\
Total & 866 & 936 & 644 & 726 & 436 & 478 \\
& $(102)$ & $(100)$ & $(100)$ & $(100)$ & $(99)$ & $(100)$ \\
\hline
\end{tabular}

NOTE: Percentages (given in parentheses) are rounded to the nearest whole number and may not total $100 \%$. 
TABLE 8

Pre-Service Students

\begin{tabular}{|c|c|c|}
\hline \multirow{2}{*}{$\begin{array}{l}\text { PRE-SERVICE } \\
\text { STUDENTS }\end{array}$} & \multicolumn{2}{|c|}{ SCHOOLS } \\
\hline & 1976 & 1977 \\
\hline $1-24$ & $\begin{array}{c}164 \\
(62.4)\end{array}$ & $\begin{array}{c}149 \\
(53.6)\end{array}$ \\
\hline $25-49$ & $\begin{array}{c}27 \\
(10.3)\end{array}$ & $\begin{array}{c}41 \\
(14.7)\end{array}$ \\
\hline $50-74$ & $\begin{array}{c}21 \\
(8.0)\end{array}$ & $\begin{array}{c}28 \\
(10.1)\end{array}$ \\
\hline $75-99$ & $\begin{array}{c}8 \\
(3.0)\end{array}$ & $\begin{array}{r}16 \\
(5.8)\end{array}$ \\
\hline Over 100 & $\begin{array}{c}43 \\
(16.3)\end{array}$ & $\begin{array}{c}44 \\
(15.8)\end{array}$ \\
\hline Total & $\begin{array}{c}263 \\
(100)\end{array}$ & $\begin{array}{c}278 \\
(100)\end{array}$ \\
\hline
\end{tabular}

NOTE: Percentages are given in parentheses.

only to institutional characteristics and not individual students. As an example, Table 5 merely indicates that in 1977, seven hundred institutions had less than two hundred of their students enrolled in criminal justice programs. These data do not indicate the actual number of students in each program. Although the data are presented by institutions, rough estimations of the numbers of students, degrees awarded, and majors can be made. ${ }^{4}$ These statistical procedures must be used with caution. However, they do provide a valuable means for gaining insights into some interesting aspects of criminal justice education.

Table 5 presents data on student enrollment. From the table, it is apparent that the vast majority of programs have student enrollment of less than two hundred. In general, there is an inverse relationship hetween the number of programs and the size of student enrollment.

Tables 6 and 7 indicate the number and type of programs awarding degrees as well as the number of students per academic major. In both cases, it appears that most programs are small in scope. The majority of programs contain less than fifty majors in either police, courts, or corrections and award fewer than ten degrees a year. It should be noted, however, that over twenty percent of the programs offering a police major contain one hundred or more students. As expected, the number of programs awarding degrees drops sharply at the graduate level. 5

Data presented in Table 8 concern the number of pre-service students (those who are intending to enter criminal justice employment for the first time after graduation) found in criminal justice programs. 
TABLE 9

Percentage of Total Student Body Majoring in Criminal Justice

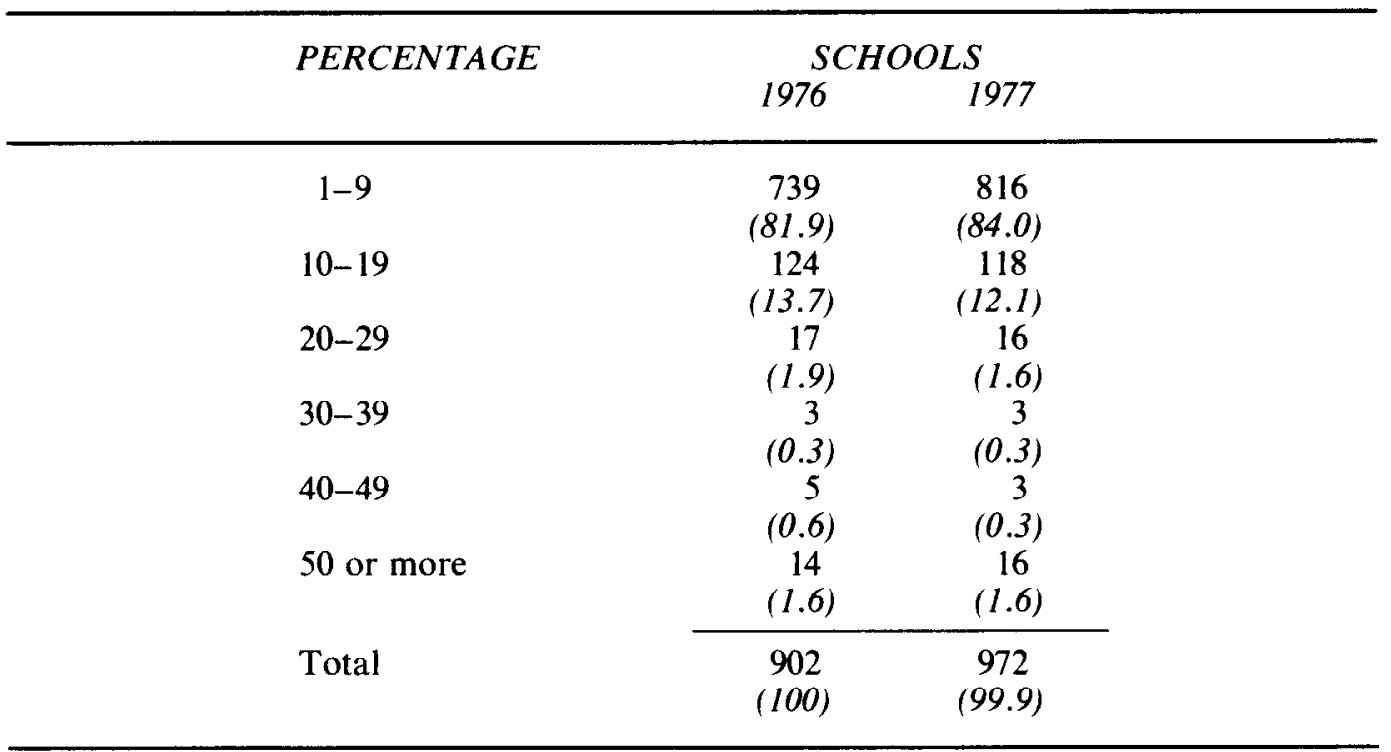

NOTE: Percentages (given in parentheses) are rounded to the nearest tenth and may not total $100 \%$.

TABLE 10

Percentage of Criminal Justice Students Majoring in Police, Corrections, AND COURTS

\begin{tabular}{|c|c|c|c|c|c|c|}
\hline \multirow[t]{3}{*}{ PERCENTAGE } & \multicolumn{6}{|c|}{ ACADEMIC MAJOR } \\
\hline & \multicolumn{2}{|c|}{ Police } & \multicolumn{2}{|c|}{ Corrections } & \multicolumn{2}{|c|}{ Courts } \\
\hline & 1976 & 1977 & 1976 & 1977 & 1976 & 1977 \\
\hline $1-9$ & 60 & 69 & 296 & 332 & 305 & 337 \\
\hline & $(8)$ & (8) & (49) & (47) & (77) & (73) \\
\hline $10-19$ & 71 & 114 & 133 & 129 & 42 & 55 \\
\hline & (9) & (13) & (22) & (18) & (11) & (12) \\
\hline $20-29$ & 87 & 93 & 58 & 64 & 22 & 22 \\
\hline & (11) & (10) & (10) & (9) & (6) & (5) \\
\hline $30-39$ & 83 & 97 & 31 & 36 & 8 & 8 \\
\hline & (11) & (11) & (5) & (5) & (2) & (2) \\
\hline $40-49$ & 72 & 85 & 15 & 27 & 5 & 3 \\
\hline & (9) & (9) & (3) & (4) & (1) & (l) \\
\hline 50 or more & 403 & 444 & 75 & 115 & 12 & 34 \\
\hline & (52) & (49) & (12) & (16) & (3) & (7) \\
\hline Total & $\begin{array}{c}776 \\
(100)\end{array}$ & $\begin{array}{c}902 \\
(100)\end{array}$ & $\begin{array}{c}608 \\
(101)\end{array}$ & $\begin{array}{l}703 \\
(99)\end{array}$ & $\begin{array}{c}394 \\
(100)\end{array}$ & $\begin{array}{c}459 \\
(100)\end{array}$ \\
\hline
\end{tabular}

NOTE: Percentages (given in parentheses) are rounded to the nearest whole number and may not total $100 \%$. 
TABLE 11

Criminal Justice Programs, By TyPe of Institution and Institutional Control

\begin{tabular}{lcccc}
\hline & \multicolumn{3}{c}{ PUBLIC } & \multicolumn{2}{c}{ PRIVATE } \\
& 1976 & 1977 & 1976 & 1977 \\
\hline University & 129 & 127 & 44 & 43 \\
& $(16.7)$ & $(17.0)$ & $(17.6)$ & $(16.5)$ \\
Four-Year & 204 & 192 & 174 & 182 \\
& $(26.4)$ & $(25.6)$ & $(69.6)$ & $(70.0)$ \\
Two-Year & 439 & 430 & 32 & 35 \\
& $(56.9)$ & $(57.4)$ & $(12.8)$ & $(13.5)$ \\
\cline { 2 - 5 } Total & 772 & 749 & 250 & 260 \\
& $(100)$ & $(100)$ & $(100)$ & $(100)$ \\
\hline
\end{tabular}

NOTE: Percentages are given in parentheses.

The data indicate that the majority of programs have less than twenty-five preservice students $(53.6 \%)$. It should be noted that not all schools responded to this question. In 1977 only twenty-seven percent of the schools responded. Thus, these data should be used with caution.

Table 9 presents data showing the percentage of the entire schools' student body that majors in criminal justice (number of criminal justice majors divided by the total number of students at the institution times 100 ). The vast majority of institutions have less than ten percent of their student body majoring in criminal justice. In fact only about one program in twenty enrolls more than twenty percent of the total student body.

Finally, Table 10 presents data on the percentage of criminal justice students who major in police, corrections, or courts (number of police, corrections, or courts majors divided by the total number of criminal justice majors times 100). It is apparent that the distribution of enrollment in the police major differs from both corrections and courts majors. The majority of corrections and courts programs contain less than twenty percent of the total criminal justice enrollment ( 65 percent of correctional programs; 85 percent of courts programs). On the other hand, almost half of police programs contain fifty percent or more of the total criminal justice enrollment ( 49 percent of the programs). In short, programs offering a police major rather than corrections or courts majors tend to have the largest percentage of the total criminal justice enrollment.

\section{TYPE OF INSTITUTION}

Tables 11 through 16 present data on institutional variations in degrees awarded and student enrollment in universities and two- and four-year institutions. It was already noted (Table 4) that by far the largest number of criminal justice programs are publicly 
TABLE 12

Criminal Justice Programs, By TyPe of InStitution and Enrollment in CRIMinal Justice Program

\begin{tabular}{lcccccc} 
Students & \multicolumn{2}{c}{ FOUR-YEAR } & \multicolumn{2}{c}{ TWO-YEAR } \\
$\begin{array}{l}\text { Enrolled in } \\
\text { Criminal Justice }\end{array}$ & \multicolumn{2}{c}{ UNIVERSITY } & \multicolumn{2}{c}{ FOU } \\
Programs & 1976 & 1977 & 1976 & 1977 & 1976 & 1977 \\
\hline \multirow{2}{*}{$1-199$} & 84 & 101 & 208 & 240 & 326 & 358 \\
& $(55)$ & $(62)$ & $(68)$ & $(70)$ & $(73)$ & $(77)$ \\
$200-399$ & 30 & 24 & 65 & 65 & 78 & 77 \\
& $(20)$ & $(15)$ & $(21)$ & $(19)$ & $(18)$ & $(17)$ \\
$400-599$ & 13 & 12 & 20 & 19 & 20 & 18 \\
& $(9)$ & $(7)$ & $(7)$ & $(6)$ & $(5)$ & $(4)$ \\
$600-799$ & 7 & 8 & 8 & 11 & 12 & 8 \\
$800-999$ & $(5)$ & $(5)$ & $(3)$ & $(3)$ & $(3)$ & $(2)$ \\
& 8 & 9 & - & 3 & 8 & 1 \\
1000 or more & $(5)$ & $(6)$ & - & $(1)$ & $(2)$ & $(0)$ \\
& 10 & 10 & 6 & 7 & 2 & 2 \\
Total & $(7)$ & $(6)$ & $(2)$ & $(2)$ & $(0)$ & $(0)$ \\
\cline { 2 - 7 } & 152 & 164 & 307 & 345 & 446 & 464 \\
& $(101)$ & $(101)$ & $(101)$ & $(101)$ & $(101)$ & $(100)$ \\
\hline
\end{tabular}

NOTE: Percentages (given in parentheses) are rounded to the nearest whole number and may not total $100 \%$.

controlled. However, when institutional level is considered (Table 11), two-year, fouryear, and university programs are not equally divided into the public or private category. For example, seventy percent of private criminal justice programs are housed in fouryear institutions, while fifty-seven percent of public criminal justice programs are found in two-year institutions. Universities, however, account for equal percentages (seventeen percent) of the total number of criminal justice programs offered by both public and private institutions.

Table 12 shows that six percent of the universities have more than a thousand students enrolled in the criminal justice program. Only two two-year institutions can claim such a large enrollment. It appears that two-year programs are most likely to have a low enrollment in their criminal justice program, since seventy-seven percent of the two-year institutions have less than two hundred students. Four-year institutions seem to occupy an intermediate position.

Table 13 focuses on the number and type of criminal justice degrees awarded by universities and two- and four-year institutions. Two-year institutions awarded the largest number of associate degrees (209 two-year institutions awarded ten or more associate degrees in 1977). It appears that four-year institutions dominate the awarding of bache- 


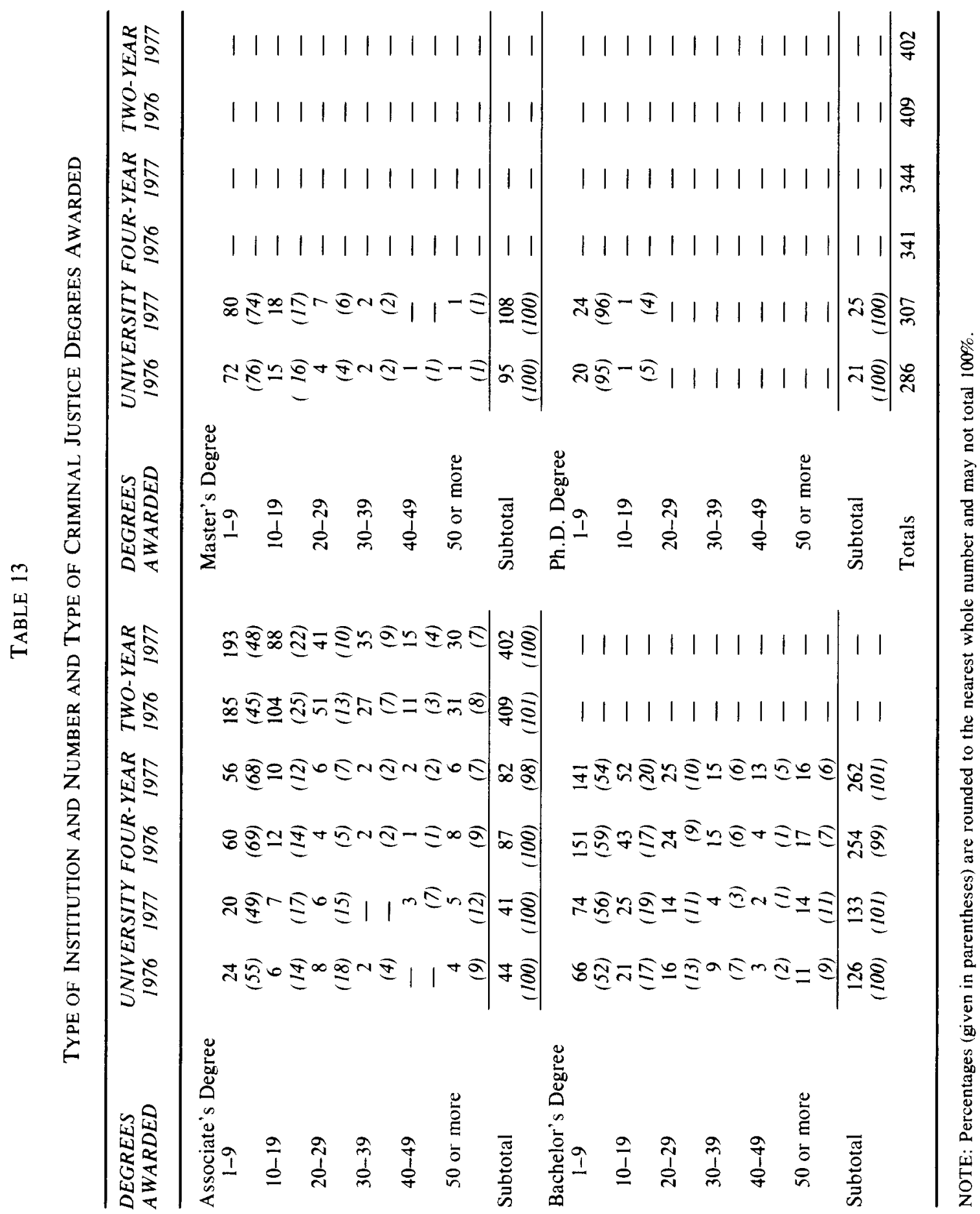


TABLE 14

Criminal Justice Programs by Type of Institution and Percentage of Total STUDENT BODY MAJORING IN CRIMINAL JUSTICE

\begin{tabular}{lcccccc}
\hline Percentage of & \multicolumn{2}{c}{ UNIVERSITY } & \multicolumn{2}{c}{ FOUR-YEAR } & \multicolumn{2}{c}{ TWO-YEAR } \\
Student Body & 1976 & 1977 & 1976 & 1977 & 1976 & 1977 \\
\hline \multirow{2}{*}{$1-9$} & 137 & 146 & 243 & 273 & 358 & 396 \\
& $(90)$ & $(89)$ & $(80)$ & $(80)$ & $(81)$ & $(86)$ \\
$10-19$ & 9 & 12 & 41 & 49 & 74 & 57 \\
& $(6)$ & $(7)$ & $(13)$ & $(14)$ & $(17)$ & $(12)$ \\
$20-29$ & 2 & 1 & 8 & 9 & 7 & 6 \\
& $(1)$ & $(1)$ & $(3)$ & $(3)$ & $(2)$ & $(1)$ \\
$30-39$ & - & 2 & 2 & - & 1 & 1 \\
$40-49$ & - & $(1)$ & $(1)$ & - & $(0)$ & $(0)$ \\
& 1 & - & 4 & 3 & - & - \\
50 or more & $(1)$ & - & $(1)$ & $(1)$ & - & - \\
& 3 & 3 & 7 & 9 & 3 & 3 \\
Total & $(2)$ & $(2)$ & $(2)$ & $(3)$ & $(1)$ & $(1)$ \\
& 152 & 164 & 305 & 343 & 443 & 463 \\
& $(100)$ & $(100)$ & $(100)$ & $(101)$ & $(101)$ & $(100)$
\end{tabular}

NOTE: Percentages (given in parentheses) are rounded to the nearest whole number and may not total $100 \%$.

lor's degrees. Eighty-two four-year institutions offered a two-year degree. Obviously, master's and Ph.D. degrees were awarded solely by universities. About three-fourths $(\mathrm{N}=80)$ of the universities surveyed awarded less than ten master's degrees. We found only one university that awarded more than ten Ph.D.s in criminal justice. Ninety-six percent $(\mathrm{N}=24)$ of the universities awarded fewer than ten $\mathrm{Ph} . \mathrm{D}$. degrees.

Table 14 reflects the percentage of the total student body that majored in criminal justice in universities and two- and four-year institutions. As we found before, the vast majority of institutions have less than ten percent of their total student body majoring in criminal justice (Table 9). Table 14 indicates that the type of institution does not affect this finding. That is, all three types of institutions have approximately the same number of programs with less than ten percent of the student body majoring in criminal justice.

Table 15 suggests that universities and two- and four-year institutions were quite similar in the relative number of police, corrections, and courts majors. For example, thirty percent of the universities, thirty-six percent of the four-year institutions, and twenty-six percent of the two-year institutions had fewer than twenty-five police majors. However, when examining the absolute frequencies, we see that eighty-eight two-year institutions had more than a hundred police majors, whereas only thirty-eight universities and seventy-five four-year programs could claim such a large number. It should also be noted that none of the two-year institutions had more than seventy-five courts majors. 
TABLE 15

Criminal Justice Program, By Type of Institution and Number of Police, CORRECTIONS, AND COURTS MAJORS

\begin{tabular}{|c|c|c|c|c|c|c|}
\hline \multirow{2}{*}{$\begin{array}{l}\text { CRIMINAL } \\
\text { JUSTICE MAJORS }\end{array}$} & \multicolumn{2}{|c|}{ UNIVERSITY } & \multicolumn{2}{|c|}{ FOUR-YEAR } & \multicolumn{2}{|c|}{ TWO-YEAR } \\
\hline & 1976 & 1977 & 1976 & 1977 & 1976 & 9177 \\
\hline \multicolumn{7}{|l|}{ Police Majors } \\
\hline \multirow[t]{2}{*}{$1-24$} & 46 & 46 & 113 & 122 & 99 & 114 \\
\hline & $(3 I)$ & (30) & (37) & (36) & (24) & (26) \\
\hline \multirow[t]{2}{*}{$25-49$} & 29 & 38 & 57 & 76 & 100 & 142 \\
\hline & (19) & $(25)$ & (19) & (22) & (24) & (32) \\
\hline \multirow[t]{2}{*}{$50-74$} & 15 & 15 & 34 & 45 & 70 & 68 \\
\hline & $(10)$ & $(10)$ & (11) & (13) & (17) & (15) \\
\hline \multirow[t]{2}{*}{$75-99$} & 11 & 16 & 28 & 20 & 51 & 31 \\
\hline & (7) & (10) & (9) & (6) & (12) & (7) \\
\hline \multirow[t]{2}{*}{100 or more } & 49 & 38 & 70 & 75 & 93 & 88 \\
\hline & (33) & (25) & (23) & (22) & (23) & (20) \\
\hline \multirow[t]{2}{*}{ Subtotal } & 150 & 153 & 302 & 338 & 413 & 443 \\
\hline & $(100)$ & $(100)$ & (99) & (99) & $(100)$ & $(100)$ \\
\hline \multicolumn{7}{|l|}{ Corrections Majors } \\
\hline \multirow[t]{2}{*}{$1-24$} & 90 & 88 & 176 & 193 & 205 & 217 \\
\hline & (63) & $(6 I)$ & (73) & (70) & (73) & (72) \\
\hline \multirow[t]{2}{*}{$25-49$} & 23 & 30 & 39 & 48 & 42 & 53 \\
\hline & (16) & $(2 I)$ & (16) & (17) & (15) & (18) \\
\hline \multirow[t]{2}{*}{$50-74$} & 15 & 10 & 14 & 18 & 14 & 17 \\
\hline & (11) & (7) & $(6)$ & (6) & (5) & (6) \\
\hline \multirow[t]{2}{*}{$75-99$} & 4 & 11 & 4 & 5 & 8 & 8 \\
\hline & (3) & (8) & (2) & (2) & (3) & (3) \\
\hline \multirow[t]{2}{*}{100 or more } & 10 & 6 & 9 & 13 & 10 & 7 \\
\hline & (7) & (4) & (4) & (5) & (4) & (2) \\
\hline \multirow[t]{2}{*}{ Subtotal } & 142 & 145 & 242 & 277 & 279 & 302 \\
\hline & $(100)$ & $(10 I)$ & $(101)$ & $(100)$ & $(100)$ & $(101)$ \\
\hline \multicolumn{7}{|l|}{ Courts Majors } \\
\hline \multirow[t]{2}{*}{$1-24$} & 97 & 101 & 152 & 180 & 147 & 152 \\
\hline & $(84)$ & $(86)$ & $(92)$ & (90) & (96) & (95) \\
\hline \multirow[t]{2}{*}{$25-49$} & 12 & 11 & 9 & 16 & 3 & 6 \\
\hline & $(10)$ & (9) & (5) & $(8)$ & (2) & (4) \\
\hline \multirow[t]{2}{*}{$50-74$} & 4 & 5 & 3 & 2 & 3 & 1 \\
\hline & (3) & (4) & (2) & (l) & (2) & (l) \\
\hline \multirow[t]{2}{*}{$75-99$} & 2 & - & 1 & 1 & - & - \\
\hline & (2) & - & (l) & (l) & - & - \\
\hline \multirow[t]{2}{*}{100 or more } & 1 & 1 & 1 & 1 & - & - \\
\hline & (I) & (1) & (I) & (1) & - & - \\
\hline \multirow[t]{2}{*}{ Subtotal } & 116 & 118 & 166 & 200 & 153 & 159 \\
\hline & $(100)$ & $(100)$ & $(101)$ & $(101)$ & $(100)$ & $(100)$ \\
\hline Totals & 408 & 416 & 710 & 815 & 845 & 904 \\
\hline
\end{tabular}

NOTE: Percentages (given in parentheses) are rounded to the nearest whole number and may not total $100 \%$. 
TABLE 16

Criminal Justice Programs, by Type of Institution and Percentage of Criminal Justice Students Majoring in Police, Corrections, and Courts

\begin{tabular}{|c|c|c|c|c|c|c|}
\hline \multirow{2}{*}{\multicolumn{3}{|c|}{ PERCENTAGEOFCRIMINAL UNIVERSITY }} & \multicolumn{2}{|c|}{ FOUR-YEAR } & \multicolumn{2}{|c|}{$T W O-Y E A R$} \\
\hline & & & 1976 & 1977 & 1976 & 1977 \\
\hline \multicolumn{7}{|l|}{ Police Majors } \\
\hline $1-9$ & $\begin{array}{c}21 \\
(16)\end{array}$ & $\begin{array}{c}24 \\
(16)\end{array}$ & $\begin{array}{l}18 \\
(7)\end{array}$ & $\begin{array}{l}27 \\
(9)\end{array}$ & $\begin{array}{l}21 \\
(5)\end{array}$ & $\begin{array}{l}18 \\
(4)\end{array}$ \\
\hline $10-19$ & 15 & 18 & 25 & 41 & 31 & 59 \\
\hline & $(11)$ & $(12)$ & $(10)$ & (13) & $(8)$ & (13) \\
\hline $20-29$ & 15 & 16 & 28 & 27 & 44 & 49 \\
\hline $30-39$ & 14 & 15 & 27 & 37 & 42 & 44 \\
\hline & (II) & $(10)$ & (11) & (12) & $(l l)$ & $(10)$ \\
\hline $40-49$ & $\begin{array}{l}12 \\
(9)\end{array}$ & $\begin{array}{l}14 \\
(9)\end{array}$ & $\begin{array}{l}19 \\
(8)\end{array}$ & $\begin{array}{l}19 \\
(6)\end{array}$ & $\begin{array}{c}41 \\
(10)\end{array}$ & $\begin{array}{l}52 \\
(12)\end{array}$ \\
\hline 50 or more & 55 & 61 & 132 & $\begin{array}{l}(0) \\
162\end{array}$ & 215 & 221 \\
\hline & $(42)$ & (41) & (53) & (52) & (55) & $(50)$ \\
\hline Subtotal & 132 & 148 & 249 & 313 & 394 & 443 \\
\hline & $(100)$ & (99) & $(100)$ & (101) & $(100)$ & $(100)$ \\
\hline \multicolumn{7}{|l|}{ Corrections Majors } \\
\hline $1-9$ & $\begin{array}{r}59 \\
(48)\end{array}$ & $\begin{array}{c}67 \\
(48)\end{array}$ & 86 & 106 & $\begin{array}{l}150 \\
(55)\end{array}$ & 158 \\
\hline \multirow{2}{*}{$10-19$} & 33 & 24 & $\begin{array}{c}1411 \\
51\end{array}$ & $\begin{array}{c}1+1) \\
51\end{array}$ & 49 & 54 \\
\hline & (27) & (17) & (24) & (20) & (18) & (18) \\
\hline \multirow[t]{2}{*}{$20-29$} & 10 & 13 & 24 & 25 & 24 & 26 \\
\hline & (8) & (9) & (II) & $(10)$ & (9) & (9) \\
\hline \multirow[t]{2}{*}{$30-39$} & 6 & 5 & 13 & 9 & 12 & 21 \\
\hline & (5) & (3) & (6) & (3) & (4) & (7) \\
\hline \multirow[t]{2}{*}{$40-49$} & 3 & 7 & 8 & 14 & 4 & 6 \\
\hline & (2) & (5) & (4) & (5) & (1) & (2) \\
\hline \multirow[t]{2}{*}{50 or more } & 13 & 24 & 27 & 56 & 35 & 35 \\
\hline & (10) & (17) & (13) & (2I) & (13) & \\
\hline \multirow[t]{2}{*}{ Subtotal } & 124 & 140 & 209 & 261 & 274 & 300 \\
\hline & $(100)$ & (99) & (99) & $(100)$ & $(100)$ & $(101)$ \\
\hline \multicolumn{7}{|l|}{ Courts Majors } \\
\hline \multirow[t]{2}{*}{$1-9$} & 76 & 82 & 104 & 120 & 124 & 135 \\
\hline & (77) & (72) & (72) & (65) & (83) & (85) \\
\hline \multirow[t]{2}{*}{$10-19$} & 9 & 12 & 19 & 26 & 14 & 16 \\
\hline & (9) & (II) & (13) & (14) & (9) & (10) \\
\hline \multirow[t]{2}{*}{$20-29$} & 7 & 7 & 8 & 10 & 7 & 5 \\
\hline & (7) & (6) & (6) & (5) & (5) & (3) \\
\hline \multirow[t]{2}{*}{$30-39$} & 1 & 1 & 5 & 7 & 2 & - \\
\hline & (1) & (I) & (3) & (4) & (I) & - \\
\hline \multirow[t]{2}{*}{$40-49$} & 3 & - & - & 2 & 2 & 1 \\
\hline & (3) & - & - & (l) & (l) & (I) \\
\hline \multirow[t]{2}{*}{50 or more } & 3 & 12 & 9 & 21 & - & 1 \\
\hline & (3) & (10) & (6) & (II) & - & (1) \\
\hline Subtotal & 99 & 114 & 145 & 186 & 149 & 158 \\
\hline & $(100)$ & $(100)$ & $(100)$ & $(100)$ & (99) & (100) \\
\hline Totals & 355 & 402 & 603 & 760 & 817 & 901 \\
\hline
\end{tabular}

NOTE: Percentages (given in parentheses) are rounded to the nearest whole number and may not total $100 \%$. 
TABLE 17

Criminal Justice Programs, By Institutional Control and Enrollment in Criminal Justice Program

\begin{tabular}{lcccc}
\hline \multirow{2}{*}{$\begin{array}{l}\text { Students in } \\
\text { Criminal Justice }\end{array}$} & \multicolumn{2}{c}{ PUBLIC } & \multicolumn{2}{c}{ PRIVATE } \\
Programs & 1976 & 1977 & 1976 & 1977 \\
\hline \multirow{2}{*}{$1-199$} & 460 & 507 & 155 & 190 \\
& $(66)$ & $(69)$ & $(75)$ & $(79)$ \\
$200-399$ & 138 & 132 & 35 & 33 \\
& $(20)$ & $(18)$ & $(17)$ & $(14)$ \\
$400-599$ & 46 & 42 & 7 & 7 \\
& $(7)$ & $(6)$ & $(3)$ & $(3)$ \\
$600-799$ & 22 & 20 & 5 & 7 \\
& $(3)$ & $(3)$ & $(2)$ & $(3)$ \\
$800-999$ & 13 & 10 & 3 & 3 \\
& $(2)$ & $(1)$ & $(1)$ & $(1)$ \\
1000 or more & 16 & 19 & 2 & - \\
& $(2)$ & $(3)$ & $(1)$ & - \\
\hline & 695 & 730 & 207 & 240 \\
& $(100)$ & $(100)$ & $(99)$ & $(100)$ \\
\hline
\end{tabular}

NOTE: Percentages (given in parentheses) are rounded to the nearest whole number and may not total $100 \%$.

Table 16 indicates that in 221 (fifty percent) two-year institutions, more than half of the criminal justice students major in police, but that in only sixty-one universities (forty-one percent) is the police curriculum the most frequent choice for the criminal justice major. Compared with two-year institutions and universities, four-year institutions are more likely to have more than half of all the criminal justice students majoring in corrections (twenty-one percent). Twelve universities (ten percent) and twenty-one four-year institutions (eleven percent) indicated that over half of their criminal justice students specialize in courts. In two-year institutions, on the other hand, it seems that majoring in courts is the least frequent choice among criminal justice students.

\section{INSTITUTIONAL CONTROL}

Tables 17 through 21 present data on criminal justice degrees awarded and student enrollment in public and private institutions. Table 17 shows that private institutions are somewhat more likely to have less than two hundred criminal justice majors (seventynine percent) than their publicly controlled counterparts (sixty-nine percent). Furthermore, nineteen public institutions enroll more than a thousand criminal justice students. 


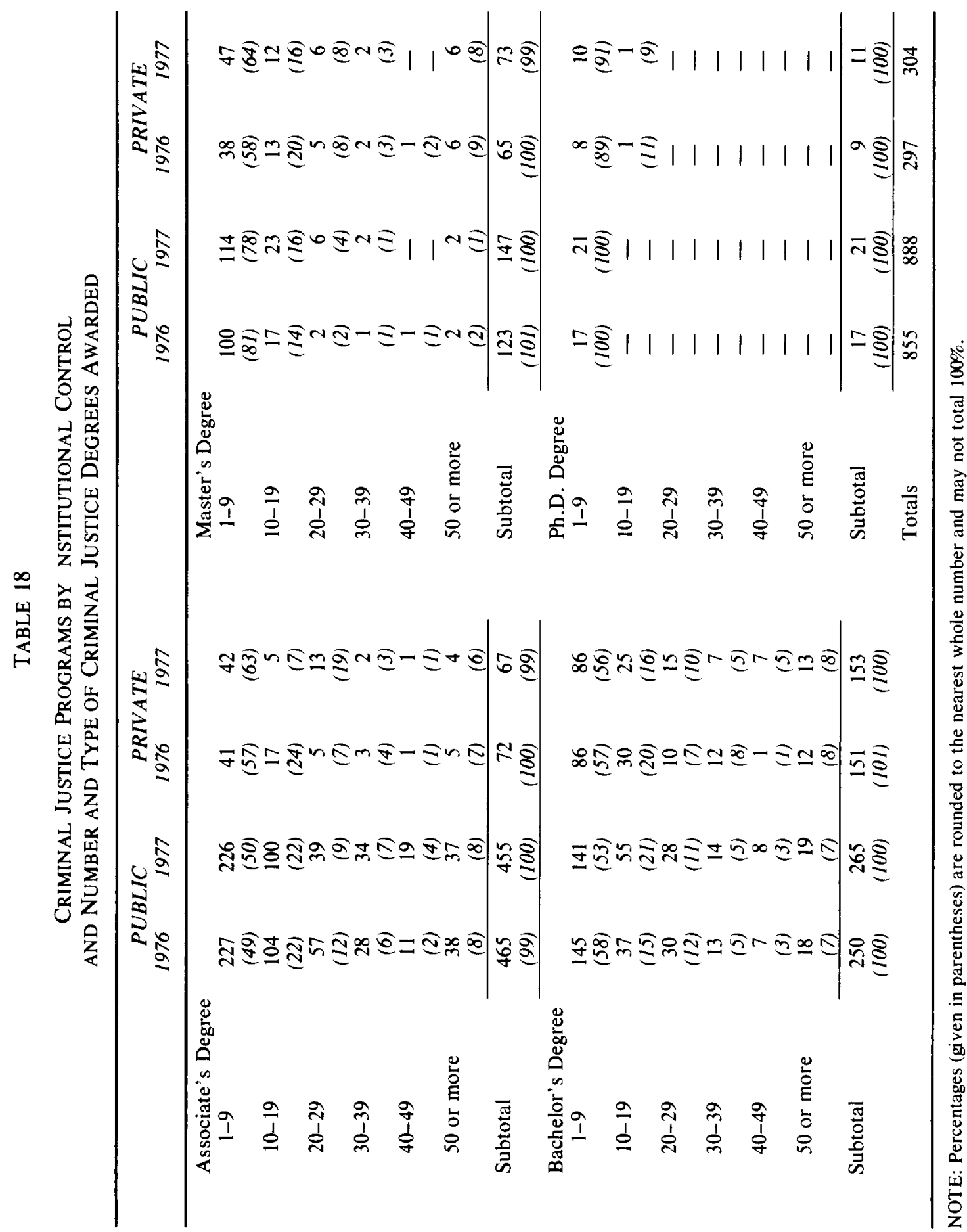


TABLE 19

Criminal Justice Programs, By Institutional Control and Percentage of TOTAL STUdent Body Majoring in CRIMINAL JuSTICE

\begin{tabular}{|c|c|c|c|c|}
\hline \multirow{2}{*}{$\begin{array}{l}\text { Percentage of Total } \\
\text { Student Body }\end{array}$} & \multicolumn{2}{|c|}{$P U B L I C$} & \multicolumn{2}{|c|}{ PRIVATE } \\
\hline & 1976 & 1977 & 1976 & 1977 \\
\hline \multirow[t]{2}{*}{$1-9$} & 585 & 631 & 150 & 181 \\
\hline & (85) & $(86)$ & (73) & (76) \\
\hline \multirow[t]{2}{*}{$10-19$} & 88 & 81 & 36 & 37 \\
\hline & (13) & (1ll) & (18) & (16) \\
\hline \multirow[t]{2}{*}{$20-29$} & 8 & 5 & 9 & 11 \\
\hline & (1) & (I) & (4) & (5) \\
\hline \multirow[t]{2}{*}{$30-39$} & - & 3 & 3 & - \\
\hline & - & $(0)$ & (2) & - \\
\hline \multirow[t]{2}{*}{$40-49$} & 3 & - & 2 & 3 \\
\hline & $(0)$ & - & (l) & (I) \\
\hline \multirow[t]{2}{*}{50 or more } & 8 & 10 & 5 & 5 \\
\hline & (l) & (1) & (2) & (2) \\
\hline \multirow[t]{2}{*}{ Total } & 692 & 730 & 205 & 237 \\
\hline & $(100)$ & (99) & $(100)$ & $(100)$ \\
\hline
\end{tabular}

NOTE: Percentages (given in parentheses) are rounded to the nearest whole number and may not total $100 \%$.

Such large enrollments are not found in private institutions. Table 18 reflects the number and type of criminal justice degrees awarded in both public and private institutions. Thirty-seven public institutions and four private institutions awarded over fifty associate degrees in criminal justice. For bachelor's degrees, Table 18 indicates that nineteen public and thirteen private schools awarded more than fifty bachelor's degrees. Private institutions appear to most likely to have awarded more than fifty master's degrees.

Table 19 provides data on the percentage of the total student body in private and public schools majoring in criminal justice. Public institutions have a smaller percentage of their students majoring in criminal justice than private institutions. That is, in only fourteen percent of the public institutions, more than ten percent of the students chose a criminal justice major. Twenty-four percent of the private institutions, however, have more than ten percent of the student body majoring in criminal justice.

Tables 20 and 21 focus on the number of police, corrections, and courts majors in public and private institutions. Table 20 indicates that 143 (twenty percent) public and fifty-seven (twenty-five percent) private institutions have more than a hundred police majors. In twenty-eight percent of the public institutions and in thirty-five percent of the private institutions, there are fewer than twenty-five police majors. Similarly, in sixtyeight percent of the public and in seventy-one percent of the private schools, there are fewer than twenty-five corrections majors. In short, it appears that the type of institu- 
TABLE 20

Criminal Justice Programs, By Institutional Control and Number of STUdents Majoring IN POLICE, CORRECTIONS, AND COURTS

\begin{tabular}{|c|c|c|c|c|}
\hline & \multicolumn{2}{|c|}{$P U B L I C$} & \multicolumn{2}{|c|}{ PRIVATE } \\
\hline & 1976 & 1977 & 1976 & 1977 \\
\hline \multicolumn{5}{|l|}{ Police Majors } \\
\hline $1-24$ & $\begin{array}{l}184 \\
(28)\end{array}$ & $\begin{array}{l}199 \\
(28)\end{array}$ & $\begin{array}{c}74 \\
(36)\end{array}$ & $\begin{array}{c}82 \\
(35)\end{array}$ \\
\hline \multirow[t]{2}{*}{$25-49$} & 152 & 201 & 33 & 54 \\
\hline & (23) & (29) & (16) & (23) \\
\hline \multirow[t]{2}{*}{$50-74$} & 94 & 107 & 25 & 21 \\
\hline & (14) & (15) & (12) & (9) \\
\hline \multirow[t]{2}{*}{$75-99$} & 74 & 50 & 16 & 17 \\
\hline & (11) & (7) & (8) & (7) \\
\hline \multirow[t]{2}{*}{100 or more } & 156 & 143 & 55 & 57 \\
\hline & (24) & (20) & (27) & (25) \\
\hline \multirow[t]{2}{*}{ Subtotal } & 660 & 700 & 203 & 231 \\
\hline & $(100)$ & (99) & (99) & (99) \\
\hline \multicolumn{5}{|l|}{ Corrections Majors } \\
\hline \multirow[t]{2}{*}{$1-24$} & 352 & 368 & 118 & 128 \\
\hline & $(70)$ & (68) & (75) & (71) \\
\hline \multirow[t]{2}{*}{$25-49$} & 82 & 99 & 21 & 31 \\
\hline & (16) & (18) & (13) & (17) \\
\hline \multirow[t]{2}{*}{$50-74$} & 34 & 36 & 9 & 9 \\
\hline & (7) & (7) & (6) & (5) \\
\hline \multirow[t]{2}{*}{$75-99$} & 15 & 19 & 1 & 5 \\
\hline & (3) & (4) & (l) & (3) \\
\hline \multirow[t]{2}{*}{100 or more } & 21 & 18 & 8 & 8 \\
\hline & (4) & (2) & (5) & (4) \\
\hline \multirow[t]{2}{*}{ Subtotal } & 504 & 540 & 157 & 181 \\
\hline & $(100)$ & (99) & $(100)$ & $(100)$ \\
\hline \multicolumn{5}{|l|}{ Courts Majors } \\
\hline \multirow[t]{2}{*}{$1-24$} & 293 & 313 & 102 & 117 \\
\hline & (93) & (92) & (87) & (88) \\
\hline \multirow[t]{2}{*}{$25-49$} & 13 & 21 & 10 & 12 \\
\hline & (4) & (6) & (9) & (9) \\
\hline \multirow[t]{2}{*}{$50-74$} & 8 & 5 & 2 & 3 \\
\hline & (3) & (1) & (2) & $(2)$ \\
\hline \multirow[t]{2}{*}{$75-99$} & 1 & 1 & 2 & - \\
\hline & $(0)$ & $(0)$ & (2) & - \\
\hline \multirow[t]{2}{*}{100 or more } & 1 & 1 & 1 & 1 \\
\hline & $(0)$ & (0) & (1) & (1) \\
\hline \multirow[t]{2}{*}{ Subtotal } & 316 & 341 & 117 & 133 \\
\hline & $(100)$ & (99) & (101) & (100) \\
\hline Total & 1480 & 1581 & 477 & 545 \\
\hline
\end{tabular}

NOTE: Percentages (given in parentheses) are rounded to the nearest whole number and may not total $100 \%$. 
TABLE 21

Criminal Justice Programs, by Institutional Control and Percentage of Criminal Justice Students Majoring in Police, Corrections, and Courts

\begin{tabular}{|c|c|c|c|c|}
\hline $\begin{array}{l}\text { Percentage of } \\
\text { Majors }\end{array}$ & \multicolumn{2}{|c|}{ PUBLIC } & \multicolumn{2}{|c|}{ PRIVATE } \\
\hline \multicolumn{5}{|l|}{ Police Majors } \\
\hline $1-9$ & $\begin{array}{l}51 \\
(8)\end{array}$ & $\begin{array}{l}57 \\
(8)\end{array}$ & $\begin{array}{c}9 \\
(5)\end{array}$ & $\begin{array}{l}12 \\
(6)\end{array}$ \\
\hline \multirow[t]{2}{*}{$10-19$} & 60 & 97 & 11 & 16 \\
\hline & (10) & (14) & (6) & (7) \\
\hline \multirow{2}{*}{$20-29$} & 69 & 76 & 17 & 15 \\
\hline & (12) & (II) & (10) & (7) \\
\hline \multirow[t]{2}{*}{$30-39$} & 69 & 82 & 14 & 14 \\
\hline & (12) & (I2) & (8) & (6) \\
\hline \multirow{2}{*}{$40-49$} & 57 & 68 & 15 & 17 \\
\hline & (9) & $(10)$ & (9) & (8) \\
\hline \multirow[t]{2}{*}{50 or more } & 297 & 302 & 104 & 141 \\
\hline & (49) & (44) & $(61)$ & $(66)$ \\
\hline Subtotal & $\begin{array}{c}603 \\
(100)\end{array}$ & $\begin{array}{l}682 \\
(99)\end{array}$ & $\begin{array}{l}170 \\
(99)\end{array}$ & $\begin{array}{l}215 \\
(100)\end{array}$ \\
\hline \multirow{2}{*}{\multicolumn{5}{|c|}{$\begin{array}{l}\text { Corrections Majors } \\
1-9\end{array}$}} \\
\hline & 242 & 270 & 52 & 60 \\
\hline & (52) & (5I) & (38) & (35) \\
\hline \multirow[t]{2}{*}{$10-19$} & 97 & 88 & 36 & 39 \\
\hline & $(2 l)$ & $(17)$ & (26) & (23) \\
\hline \multirow[t]{2}{*}{$20-29$} & 42 & 45 & 15 & 19 \\
\hline & (9) & (9) & (11) & (II) \\
\hline \multirow[t]{2}{*}{$30-39$} & 23 & 29 & 8 & 6 \\
\hline & (5) & (6) & (6) & (4) \\
\hline \multirow[t]{2}{*}{$40-49$} & 10 & 17 & 5 & 10 \\
\hline & (2) & (3) & (4) & (6) \\
\hline \multirow[t]{2}{*}{50 or more } & 54 & 78 & 21 & 37 \\
\hline & (11) & $(15)$ & (15) & $(22)$ \\
\hline \multirow[t]{2}{*}{ Subtotal } & 468 & 527 & 137 & 171 \\
\hline & $(100)$ & $(10 I)$ & $(100)$ & $(101)$ \\
\hline \multicolumn{5}{|l|}{ Courts Majors } \\
\hline \multirow[t]{2}{*}{$1-9$} & 234 & 265 & 69 & 69 \\
\hline & (81) & (80) & (67) & (55) \\
\hline \multirow[t]{2}{*}{$10-19$} & 27 & 28 & 15 & 26 \\
\hline & (9) & (8) & (15) & $(21)$ \\
\hline \multirow[t]{2}{*}{$20-29$} & 13 & 9 & 8 & 13 \\
\hline & (4) & (3) & (8) & (10) \\
\hline \multirow[t]{2}{*}{$30-39$} & 5 & 7 & 3 & 1 \\
\hline & (2) & (2) & (3) & (1) \\
\hline \multirow[t]{2}{*}{$40-49$} & 3 & 2 & 2 & 1 \\
\hline & (I) & (1) & (2) & (l) \\
\hline 50 or more & 6 & 19 & 6 & 15 \\
\hline & (2) & (6) & (6) & (12) \\
\hline Subtotal & 288 & 330 & 103 & 125 \\
\hline & (99) & $(100)$ & $(101)$ & $(100)$ \\
\hline Total & 1359 & 1539 & 410 & 511 \\
\hline
\end{tabular}

NOTES: Percentages (given in parentheses) are rounded to the nearest whole number and may not total $100 \%$. The total is greater than the actual number of schools because categories are not mutually exclusive. 
tional control is unrelated to the relative number of police, corrections, and courts majors.

Table 21 shows that in sixty-six percent of the private institutions over half of the criminal justice students major in police as opposed to only forty-four percent of the students in public institutions. In twenty-two percent of the private schools and in fifteen percent of the public schools, half of the criminal justice students major in corrections. Private institutions have a slightly larger percentage of their criminal justice students majoring in corrections. That is, fifty-one percent of the public institutions have less than ten percent of their criminal justice students specializing in corrections, as compared with thirty-five percent of private institutions. Finally, in six percent of the public and twelve percent of the private institutions, over half of the criminal justice students major in the area of courts.

\section{SUMMARY}

The purpose of this report was to present data that depict criminal justice education in the United States. The data were presented in as primary form as possible to allow readers to draw their own conclusions. Brief interpretations, however, were provided.

The major observations of this study may be briefly summarized. It appears that most criminal justice programs are to be found in publicly controlled, two-year institutions. Most programs are small. They usually contain less than two hundred students who generally account for less than ten percent of the institution's total student body. The majority of private programs are housed in four-year institutions, while most public programs are offered by two-year institutions. Private institutions predominantly offer the smaller programs and award the fewest degrees. Although larger in total enrollment, the criminal justice programs in public institutions contain a relatively smaller percentage of the total student body.

Overall, the police major appears to attract the largest enrollment, while the courts major seems to be the least popular specialization. The majority of students in universities and two-ycar institutions major in police while students in four-year institutions major in corrections. In addition, institutional control does not appear to be related to the number of police, correction, and courts majors.

Finally, it should be reiterated that the data presented provide only a descriptive account of selected characteristics of LEEP-funded criminal justice educational programs. Although these data do not resolve the current controversial issues in postsecondary criminal justice education, they do provide a necessary backdrop for future research.

\section{ACKNOWLEDGEMENT}

We wish to thank the Office of Criminal Justice Education and Training, Law Enforcement Assistance Administration for permission to use its data files.

In addition, we would like to thank $J$. Price Foster and Ronald Collison, Office of Criminal Justice Education and Training, LEAA; Richard H. Ward, Robert G. Culbertson, and Richter H. Moore, Jr., Academy of Criminal Justice Sciences; Fred Stone, Calvin J. Swank, Nickolas N. Paraska, and the computer staff and facilities at Youngstown State University; and the Administrative Zone at the Highway Safety Research Institute at the University of Michigan. 
This publication was developed as a committee report by the Committee for Research in Criminal Justice. Academy of Criminal Justice Sciences. The Academy has devoted journal space for its publication.

\section{NOTES}

1 The major reason an institution might not apply and thus not be represented in the data base is that LEEP contains no provisions for institutional overhead or operating costs. In addition, LEEP requires the institution to maintain a full-time LEEP coordinator. Thus, other than financial aid for their students, the institution has nothing to gain from participation in the program. Furthermore, although last year $\$ 40.5$ million in LEEP funds were distributed to participant institutions, 82.7 percent of the institutions received less than $\$ 50,000$. Thus, the institution might decide that the cost in maintaining the program would not be offset by the benefit of financial aid for its students.

2 A complete set of tables is available on request. Forward requests to Richard $\mathbf{R}$. Bennett, Highway Safety Research Institute, University of Michigan, Huron Parkway and Baxter Road, Ann Arbor, Michigan 48109.

${ }^{3}$ In addition to the absolute frequencies, percentages are also presented on the tables. Percentages are convenient when one is concerned with relative magnitudes and comparisons between groups of unequal sizes. Although the absolute number may be greatest in one category, its relative number might not. Since percentages based on small absolute numbers are often unreliable, caution must be used when interpreting percentages.

4 These estimations are made by finding the midpoint in the category and multiplying that value by the frequency of its occurrence in the category. As an example, the midpoint is calculated by simply adding the highest and lowest true limits of the category value and then dividing the sum total by two. For instance, the midpoint of the first category in Table 5 is 100 [i.e., 199.5 (highest true limits) plus 0.5 (lowest true limit) divided by two].

Again referring to Table 5 , it is now possible to roughiy estimate the total number of criminal justice students attending institutions with less than two hundred students in their criminal justice program by multiplying the frequency $(\mathrm{N}=700)$ with the midpoint $(100)$. This calculation suggests that approximately seventy thousand students were enrolled in criminal justice programs with less than two hundred students in 1977. If we want to estimate the total number of criminal justice students, we simply repeat the same procedure for each of the six categories and sum the numbers. The accuracy of this estimation depends on the validity of the assumption that the number of students is equally distributed within the category.

For purposes of calculation, the last category of Table 5 (1000 and over) was defined as ranging from 1000-1999 (midpoint: 1499.5). When dealing with open categories, one must set one's own boundaries to be able to calculate the midpoint. The selection of the upper limit of such a catcgory is necessarily arbitrary. As a general rule, it is best to be conservative since extremely large values are rare.

Roughly speaking, then, it seems that there were approximately 200,000 criminal justice students in the United States in 1977. Again, it should be emphasized that one should be very careful in the interpretation of the results of this estimation technique.

5 Using estimation procedures, approximately nine thousand associate's degrees and about seven thousand bachelor's degrees in criminal justice were awarded in 1977 (the upper true limit for the category, 50 and over, was defined as 99.5 , midpoint 74.5). Further, it seems that police majors are most prevalent (approximately 87,000). Corrections as a field of specialization is less popular (approximately 23,000 students), but a courts major is clearly the least often selected choice for the criminal justice student (approximately 7,800 students). The upper true limit for the category ( 100 and over) was defined as 499.5 (midpoint: 299.5 ).

\section{REFERENCES}

Aaron, T. J. (1965). Education and professionalism in American law enforcement. Police 9:37-41.

Ashburn, F. G., and Ward, P. E. Jr. (1973). Education and training: the moment of truth. Police chief 40 (July): 40-41. 
Baehr, M., Furcon, J., and Froemel, E. (1968). "Psychological assessment of patrolman qualifications in relation to field performance." Washington, DC: U.S. Government Printing Office.

Bennett, R. R. (1978). The effects of education on police values and performance: A multivariate analysis of an explanatory model. In Quantitative studies in criminology, ed. C. Wellford. Beverly Hills, CA: Sage Publications.

Brantingham, P. J. (1972). A model curriculum for interdisciplinary education in criminology. Criminology 10:324-35.

Brown, D. C. (1971). Education and training: Perspectives of the police role. Police 16:21-24.

Brown, L. P. (1974). The police and higher education. Criminology 12:114-24.

Bureau of the Census, U.S. Department of Commerce (1977). Statistical abstract. Washington, DC: U.S. Government Printing Office.

Cascio, W. F. (1977). Formal education and police officer performance. Journal of police science and administration 5:89-96.

Cascio, W. F., and Real, L. (1976). Educational standards for police officer personnel. Police chief 43 (Aug):54-55.

Christian, K. E. (1976). A comparison of the behavior styles of college-educated and non-college police officers." Unpublished manuscript. Michigan State University, East Lansing, Michigan.

Cohen, B., and Chaiken, J. M. (1972). "Police background characteristics and performance." New York: The New York City Rand Institute. Monograph.

Cromwell, P. F., Jr. (1972). Training-education-community understanding. Police chief (March) 39:54-56.

Finnigan, J. C. (1976). A study of relationships between college education and police performance in Baltimore, Maryland. Police chief 43 (Aug):60-62.

Gambino, F. J. (1973). Higher education for the police: Pros and cons. Law and order 21:58-66.

Geary, D. P. (1971). Experience with college educated officers. Journal of law enforcement education $1: 8-11$.

(1970). College educated cops—Three years later. Police chief 37 (Aug):59-62.

Germann, A. C. (1967). Education and professional law enforcement. Journal of criminal law, criminology and police science 58:603-09.

Gould, E. W. (1973). Does a policeman need to have a college degree to be a professional? Law and order 21:68-69.

Gourley, G. D. (1972). Higher education for police personnel. Law and order 20:34-37.

Hoover, L. T. (1975). "Police educational characteristics and curricula." United States Department of Justice monograph. Washington, DC: U.S. Government Printing Office.

Kobetz, R. W. (1975). Law enforcement and criminal justice education directory, 1975-76. Gaithersburg, MD: International Association of Chiefs of Police.

Kuykendall, J. L., and Hernandez, A. P. (1975). A curriculum development model. Police chief 42(Aug):20-25.

Lankes, G. A. (1970). How should we educate the police. Journal of criminal law, criminology and police science 61:587-92.

Lejins, P. P. (1970). "Introducing a law enforcement curriculum at a state university." United States Department of Justice monograph. Washington, DC: U.S. Government Printing Office.

Lynch, G. W. (1976). The contributions of higher education to ethical behavior in law enforcement. Journal of criminal justice 4:285-90. 
Mathias, W. J. (1969). A criminal justice curriculum for an urban society. Police chicf 36(Aug):1618.

Matarazzo, J. D., Allen, B. V., Saslow, G., and Wiens, A. N. (1964). Characteristics of successful policemen and firemen applicants. Journal of applied psychology 48:123-33.

McGreevy, T. J. (1964). "A field study of the relationship between the formal education levels of 566 police officers in St. Louis, Missouri, and their patrol performance records." Unpublished master's thesis, Michigan State University, East Lansing, Michigan.

Moynahan, J. M. (1973). Training the police officer in a liberal arts college. Police chief 40(Nov):58-60.

69.

(1969). A social science approach to education of law enforcement personnel. Police 14:66-

National Advisory Commission on Civil Disorders (1968). Report of the National Advisory Commission on Civil Disorders. Washington, DC: U.S. Government Printing Office.

National Advisory Commission on Criminal Justice Standards and Goals (1973). Police. Washington, DC: U.S. Government Printing Office.

National Commission on the Causes and Prevention of Violence (1969). To establish justice, to insure domestic tranquility. Washington, DC: U.S. Government Printing Office.

National Commission on Law Observance and Enforcement (Wickersham Commission) (1931). Report on the police. Washington, DC: U.S. Government Printing Office.

National Planning Association (1976). A nationwide survey of law enforcement criminal justice personnel needs and resources. Criminal Justice Education and Training, vol V. Washington, DC: National Planning Association.

Parker, W. L. (1973). Training and education. Police chief 40(Feb):36,37.

President's Commission on Law Enforcement and the Administration of Justice (1967). Task force repurt: The police. Washington, DC: U.S. Government Printing Office.

Prout, R. S. (1972). An analysis of associate degree programs in law enforcement. Journal of criminal law, criminology and police science 64:585-92.

Roberg, R. R. (1976). "An analysis of the relationships among higher education, belief systems and job performance of patrol officers in a municipal police department." Unpublished manuscript, University of Nebraska, Lincoln, Nebraska.

Saunders, C. B. (1970). Upgrading the American police: Education and training for better law enforrement. Washington DC: The Brookings Institute. (Pp. 79-116.)

Sherman, L. and the National Advisory Commission on Higher Education for Police Officers (1978). The quality of police education. San Francisco: Jossey-Bass.

Sherman, L. W. (1977). "Content and control of college curricula for the police." Presented at Criminal Justice Human Resources Needs and the Collegiate Response. Michigan State University, East Lansing, Michigan.

Smith, C. P. (1977). "Is relevant criminal justice education possible." Paper presented at Criminal Justice Human Resources Needs and the Collegiate Response. Michigan State University, East Lansing, Michigan.

Smith. D. C.. and Ostrom. E. (1974). The effects of training and education on police attitudes and performance: A preliminary analysis. In The potential for reform of criminal justice, ed. $\mathrm{H}$. Jacob. Beverly Hills, CA: Sage Publications.

Trojanowicz, R. C.. and Nicholson, T. G. (1976). A comparison of behavioral styles of college graduate police officers vs. noncollege-going police officers. Police chief 43(Aug):56-59.

Wilson. B. W. (1974). Education and training: An assessment of where we are and where we are going. Police chief 41(Aug):23-24\& 71 .

Witte, R. P. (1969). The dumb cop. Police chief 36( Jan):37-38. 